\title{
Hydrogeochemical Characteristics and Quality Assessment of Surface Water in an Agricultural Area in Equatorial Africa: The Mungo River Basin, South West Cameroon, Central Africa
}

\author{
Gustave Raoul Nkoue Ndondo ${ }^{*}$, Suzanne Ngo Boum ${ }^{1}$, Fricelle Song1, \\ Gloria Eneke Takem Eyong², David Eric Komba1, Bertil Nlend'2, Jacques Etame ${ }^{1}$ \\ ${ }^{1}$ Department of Earth Sciences, University of Douala, Douala, Cameroon \\ ${ }^{2}$ Institute for Geological and Mining Research, Yaoundé, Cameroon \\ Email: *raoulnkoue@yahoo.fr, suzyboum@yahoo.fr, gloriatakem@yahoo.com
}

How to cite this paper: Ndondo, G. R. N., Boum, S. N., Song, F., Eyong, G. E. T., Komba, D. E., Nlend, B., \& Etame, J. (2021). Hydrogeochemical Characteristics and Quality Assessment of Surface Water in an Agricultural Area in Equatorial Africa: The Mungo River Basin, South West Cameroon, Central Africa. Journal of Geoscience and Environment Protection, 9, 164-181.

https://doi.org/10.4236/gep.2021.93010

Received: February 3, 2021

Accepted: March 22, 2021

Published: March 25, 2021

Copyright $\odot 2021$ by author(s) and Scientific Research Publishing Inc. This work is licensed under the Creative Commons Attribution International License (CC BY 4.0).

http://creativecommons.org/licenses/by/4.0/ (c) (i) Open Access

\begin{abstract}
The Mungo River and its tributaries represent the major sources of water supply for agriculture and drinking purposes for the Douala city and the south western agricultural region of Cameroon. In this study, the surface water hydrochemistry was investigated at 12 locations to determine the hydrochemical and heavy metals characteristics and to assess the suitability for drinking and irrigational purposes. Results of water samples collected along the main channel and tributaries showed that the major ions were dominated by $\mathrm{Ca}^{2+}>\mathrm{Na}^{+}>\mathrm{Mg}^{2+}>\mathrm{K}^{+}>\mathrm{NH}_{4}^{+}$and $\mathrm{HCO}_{3}^{-}>\mathrm{NO}_{3}^{-}>\mathrm{SO}_{4}^{2-}>\mathrm{Cl}^{-}>$ $\mathrm{F}^{-}>\mathrm{PO}_{4}^{3-}$, with concentrations varying between 0 to $60 \mathrm{mg} / \mathrm{l}$. Heavy metal concentrations were relatively weak, dominated by $\mathrm{Fe}>\mathrm{Mn}>\mathrm{As}>\mathrm{Cd}>\mathrm{Zn}>$ $\mathrm{Se}$. The main hydrochemical facies types revealed primarily $52 \% \mathrm{Ca}-\mathrm{Na}-\mathrm{HCO}_{3}$ and $48 \% \mathrm{Ca}-\mathrm{Mg}-\mathrm{HCO}_{3}$. Base on Gibbs diagram and relative ion ratios, the hydrochemical characteristics are derived from weathering of silicate rocks and atmospheric source. The influence of anthropogenic factors including agro-industrial activities on the hydrochemical characteristics was less marked. The chemical composition of the water samples was compared with the drinking water standards and only the concentration of Fe was above the WHO guide limits in a single sample at Passi. The evaluation of the water quality for irrigation showed that $95 \%$ of water samples are suitable for irrigation in almost all soil types. According to the water quality index (HPI, HEI and $\mathrm{Cd}$ ), this water is considered of excellent quality for consumption. The results provide a preliminary database for sustainable management of water resource in the Mungo River basin.
\end{abstract}




\section{Keywords}

Mungo River Basin, Surface Water, Hydrochemical Characteristics, Heavy Metals, Drinking and Irrigation Suitability

\section{Introduction}

Rivers, streams and lakes, have long been important sources of water for drinking and agricultural uses. The proportion of drinking-water supplies relying on surface water is extremely variable regionally, but globally, surface water is estimated to cover about $50 \%$ of drinking water needs. As population pressures increase in many parts of the world, protecting surface water sources and preventing deterioration of their quality are becoming a fundamental requirement. Surface water interacts hydrochemically with environment in the area where they flow. The degree of these interactions significantly depends on hydro-meteorological, fluvial, anthropogenic, and geological processes (Winter et al., 1998), and affects the hydrochemical composition of water bodies on the local and regional scales (Ako et al., 2012; Sanga et al., 2020). Consequently, surface water quality is subjected to hydrochemical changes that are indicative of the climate and environment changes such as increased precipitation, evaporation, domestic and industrial activities, agriculture and breeding, human and animal consumption (Zhang et al., 2019). The hydrochemical characteristics represent an important factor determining the multi-purpose use of water (Khatri \& Tyagi. 2014; Huang et al., 2014). To better identify the basic processes affecting the chemical composition of the surface water, an understanding of the main factors controlling the ion and metal composition is required (Güler \& Thyne, 2004; Huang et al., 2014). Since anthropogenic influences (domestic and industrial uses, agrochemical loadings, irrigation and increasing exploitation of water resources), reduces the suitability of surface water and induces costly water treatment, hydrochemical investigations can help to assess the water quality for drinking and for agricultural uses.

The evaluation of water quality in most developing countries has become a relevant issue in recent years, especially due to concerns that freshwater will be a scarce resource in the future (Aminiyan et al., 2016). Measuring the concentration of heavy metals $(\mathrm{Zn}, \mathrm{Ni}, \mathrm{Pb}, \mathrm{Cd}, \mathrm{Cr}, \mathrm{As}$ and $\mathrm{Cu}$ ) and determining the Water Quality Indices (WQI: the heavy metal pollution index and heavy metal evaluation index) are essential in monitoring drinking water quality (Ghaderpoori et al., 2018). Permissible limits for various ions in drinking water are given by WHO (1993). From an agricultural perspective, the suitability of water for irrigation use can be determined by sodium percent ( $\mathrm{Na} \%)$, magnesium hazard $(\mathrm{MH})$, residual sodium carbonate (RSC), sodium adsorption ratio (SAR), permeability index (PI), salinity index (Brindha \& Kavitha, 2015).

The Mungo River basin (MRB) is located in a volcanic area where the fast 
weathering nature of volcanic materials would be an important process controlling the concentration of ions in surface and groundwater (Bartarya, 1993; Endeley et al., 2001; Ako et al., 2012). Volcanic mountains slopes are known to possess soils that are amongst the best for agriculture (Driessen\& Dudal, 1991). The fertility of soils in the MRB has promoted the development of vast industrial plantations and pre-processing factories for agricultural products. At lower altitudes in the Mungo River plain, many economic activities such as extensive plantations and agro-industries of bananas, palms, rubber have enhanced the creation of agglomerations. Throughout the course of the river, sand quarries have developed, often constituting a risk of contamination for stream water. The quality of the waters of the Mungo River and its tributaries are thus subject to the influence of discharges from domestic and agro-industrial activities and natural processes of inputs from runoff and groundwater discharges from slopes springs. To these influences, one can add the in-stream remobilization of deposited sediments, which create a strong turbidity likely to promote the transport of precipitated metals. The MRB is intensively exploited downstream, both for agricultural and agro-industrial purposes and pumping for drinking water supply. It is the main water resource for almost 6 million people, including drinking water supplies for the towns of Kumba, Muyuka, Buea, Mbanga and the megapolis of Douala and its environs. Despite the fact that water from the river is needed to maintain the productivity and daily life of the residents and the ecological balance, catchment-based hydrochemical studies of surface water in the MRB are few (Ako et al., 2012; Tabot et al., 2016). Therefore, the hydrochemichal characterization of the surface water in the MRB is significantly important to check the risk of water pollution and managing surface water resources. Early studies of the hydrochemical characteristics of surface flows, springs and groundwater in South Western Cameroon (Ako et al., 2012; Wotany et al., 2013; Ako et al., 2014, Tabot et al., 2016) showed controls of silicate minerals weathering on major ions $\left(\mathrm{Ca}^{2+}, \mathrm{Mg}^{2+}, \mathrm{Na}^{+}\right.$and $\left.\mathrm{K}^{+}\right)$while $\mathrm{NO}_{3}^{-}$and $\mathrm{Cl}^{-}$ were of anthropogenic origin. Oceanic monsoon chloride-rich/sulfate-rich rainwater seems to affect spring water chemistry at low-altitude toward the coastal part of the basin. Nitrate contamination were attributed to N-fertilizers, sewerage, animal waste, organic manure, pit latrines (Ako et al., 2014). The discharging of such groundwater to surface freshwater of the Mungo River and tributaries could alter their quality. The anthropogenic risk pollution reported by Tabot et al. (2016) for the Lake Barombi Bo, which is an important source of fresh water for the Kumba population and its surroundings (more than half a million people), could be a warning signal for the assessment and protection of surface water of the MRB.

This study aims to analyze the hydrochemical characteristics of the Mungo River Basin (MRB) to access: 1) the sources of chemical composition and 2) the suitability for drinking and irrigational purposes of surface water in the Mungo River and tributaries. 


\section{Site Description}

The MRB extends from $4^{\circ} 05^{\prime}-5^{\circ} 30^{\prime} \mathrm{N} ; 9^{\circ} 20^{\prime}-9^{\circ} 40^{\prime} \mathrm{E}$ is located both in the South West and Littoral Regions of Cameroun (Central Africa). It covers a surface area of $4200 \mathrm{~km}^{2}$ and spreads over altitudes between the coastal plain and the mountain ranges (Figure 1), shaped into four geomorphological units: 1) the coastal plains (altitude $<150 \mathrm{~m}$ ); 2) undulating low hills (200 $\mathrm{m}<$ altitude $<500 \mathrm{~m}$ ); 3) high hills dotted with valleys and interfluves $(500 \mathrm{~m}<$ altitude $<1500 \mathrm{~m})$ and 4) mountain massifs of Mount Rumpi, Mount Bakossi and Mount Cameroon (altitude $>1500 \mathrm{~m})$.

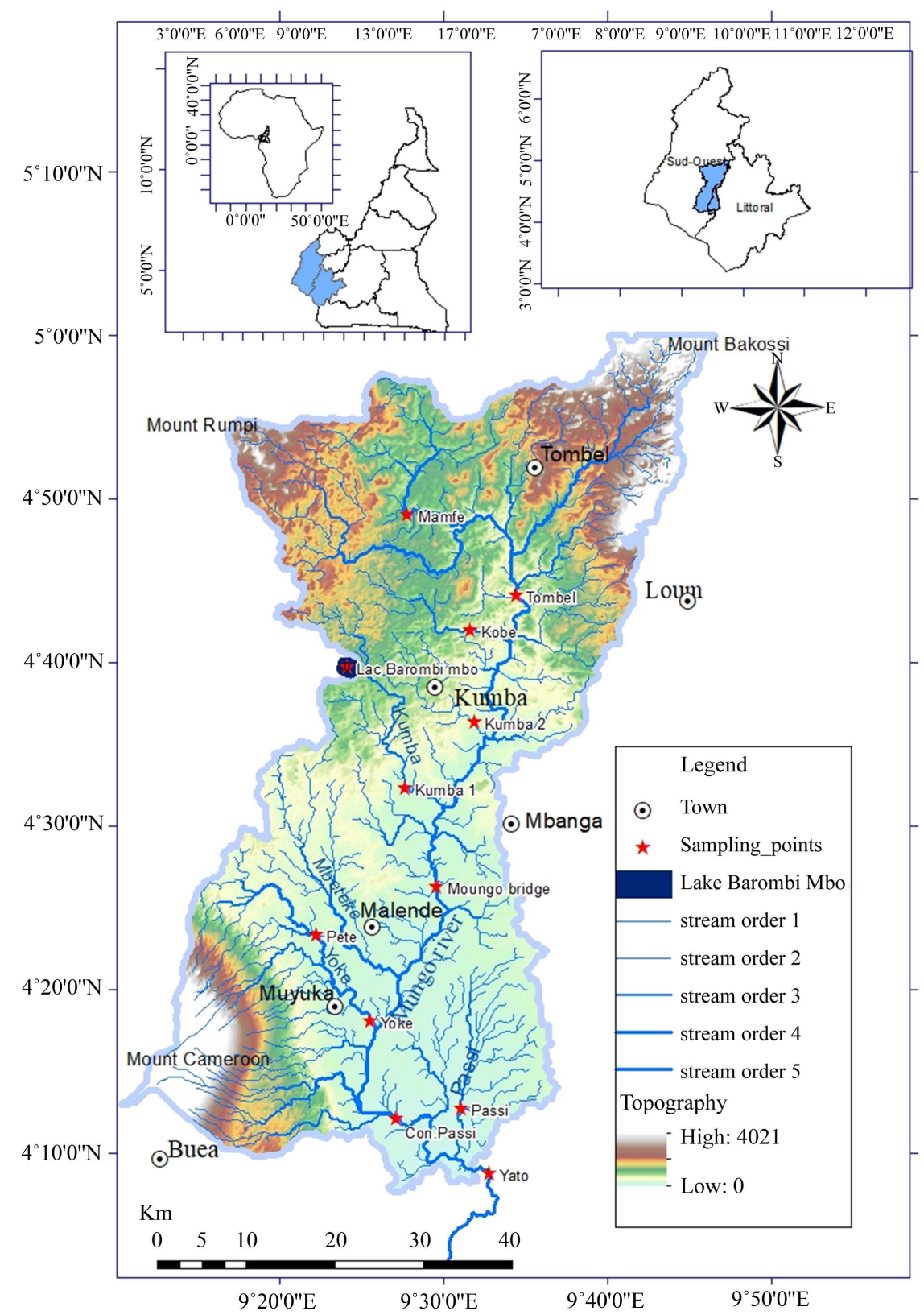

Figure 1. Map showing the location of the settlements within the Moungo River basin and the sampling stations. 
The Mungo River and its tributaries drain large agricultural areas as well as semi-urban and urban areas where the population density reach up to 150 inhabitants $/ \mathrm{km}^{2}$ (Ako et al., 2014). Its hydrographic network extends from the Rumpi and Bakossi mountains and is joined on the right bank by Kobe, Kumba, Mbeteke, Yoke streams as well as numerous torrents that run down the slopes of the mountains. On the left bank, the MRB network is sparsely densified, mainly made up of the upstream torrents from Mont Bakossi and the Passi stream in the coastal plain. The Mungo River flows southward through the upstream valley of volcanic materials. At lower altitudes downstream, it flows through sedimentary deposits of the coastal plain, before entering the mangrove swamps at the Wouri estuary, after a course of $150 \mathrm{~km}$ (Olivry, 1986). West of the MRB, there is a large natural volcanic lake, the Barombi Mbo, which is the source of Kumba stream and an important reservoir of fresh water for the Kumba town and its surrounding.

The climate is of equatorial type with two quite distinct seasons. A rainy season extending from June to October is influenced by humid monsoon summer with maximum rainfall in September. The dry season extends from November to May. Ten-year (from 2003-2013) meteorological data from local stations (Malende, Meandja, Mukondje, Kompina, Penda Mboko, Matouke, Missellele and Sonne) show that the mean annual air temperature was $28^{\circ} \mathrm{C}$ in the southern coastal plain, and lower than $21^{\circ} \mathrm{C}$ at the northern mountainous area. About 185 rainfall days are recorded per year with annual rainfall varying from one station to another between a minimum of $1571 \mathrm{~mm}$ and a maximum of $3432 \mathrm{~mm}$, of which 70\% occurs during the period from June to October.

The MRB lies on a Pre-Cambrian basement made of crystalline schist, gneiss and intrusive granites which constitute the northern edge of the Congo craton. In the south of the basin there is a coastal plain of $20 \mathrm{~m}$ altitude and hills with altitude less than $60 \mathrm{~m}$ where the crystalline basement is covered with essentially sedimentary rocks of Cretaceous to Cenozoic age, made up of sands and sandstones (Martin \& Sieffermann, 1966), above which are found recent volcanic rocks (basaltic lava and deposits volcanoclastic) (Tamen et al., 2007). Thick alluvia are found downstream in the coastal border of the basin, where sedimentary series dominate. The north of the coastal plain is characterized by volcanic rocks of diverse origin, which according to Gèze (1943) are made up of old volcanic series (basalts and andesites), medium age volcanic series (acidic volcanic rocks and trachytes) and young volcanic series (basalts and lapillis).

Three types of soil are developed in the MRB area, 1) yellow and red ferralitic soil in the coastal plain (60\%), developed on sandstone bedrock Sieffermann (1973); 2) hydromorphic soil (30\%), founded in the mangrove at coastal border and in the swampy wetland; and 3) brown young soil on the slopes of the mountains (10\%), derived from basalts and lapillis of the young volcanic series. Well preserved volcanic cones provide gently sloping lava flows covered by ash and pumice deposits, from which soils have developed to produce fertile arable lands devoted to intensive agriculture. The main types of land covers are green 
rainforest in the north (40\%), Atlantic littoral forest in the south (11\%), farmland $(45 \%)$ and water area $(4 \%)$. The MRB is one of the greatest agricultural area of the southern Cameroon, including a large proportion of surface watering to support banana production and other crops in the region.

\section{Sampling}

Sampling was done during the rainy season in August 2016. Surface water samples were collected at 12 locations, distributed as follows: 5 samples along the main course of the Mungo river (Manfe bridge, Tombel bridge, Mungo bridge, Passi confluent, and Yato bridge); 6 samples in the main tributaries (Kobe, Kumba 1 and 2, Pete, Yoke and Passi) and 1 sample in the lake Barombi Mbo (Figure 1). The sampling polyethylene bottles (PET) were pre-washed by soaking in $15 \mathrm{~N}$ nitric acid for six hours and then thoroughly rinsed with deionized water and finally dried in an electric oven. A multi-parameter instrument (YSI. Inc) was used to measure the $\mathrm{pH}$, temperature, total dissolved solid (TDS) and electrical conductivity (EC). The water samples were filtered using a $0.45 \mu \mathrm{m}$ cellulose acetate membrane syringe filter. The syringe filters were rinsed with the sampling water before the collection of the water sample. Sample for cations and heavy metals analysis were collected into an $80 \mathrm{ml}$ pre-cleaned PET bottle and acidified with two drops of $15 \mathrm{~N}$ nitric acid. An aliquot of non-acidified water was collected in a $125 \mathrm{ml}$ PET bottle for the alkalinity titration and anion analysis. The sampled bottles were carefully sealed using Parafilm film and stored in a refrigerator at $4^{\circ} \mathrm{C}$.

\section{Analytical Methods}

Concentrations of major cations $\left(\mathrm{Na}^{+}, \mathrm{K}^{+}, \mathrm{Ca}^{2+}\right.$ and $\left.\mathrm{Mg}^{2+}\right)$ and major anions $\left(\mathrm{F}^{-}\right.$, $\mathrm{Cl}^{-}, \mathrm{NO}_{3}^{-}, \mathrm{PO}_{4}^{3-}, \mathrm{SO}_{4}^{2-}$ ) were measured by ionic chromatography (HPLC DIONEX Ics-90) with a precision of $\pm 2 \%$ at the Laboratory of Water Analysis (LAGE) of the Institute of Geological and Mining Research (IRGM). $\mathrm{HCO}_{3}^{-}$ was derived from headline volumetric titration of alkalinity with hydrochloric acid using Grant method, with an analytical error of $<3 \%$. The charge balance error $\left(\mathrm{CBE}=\left(\sum\right.\right.$ cations $-\sum$ anions $) /\left(\sum\right.$ cations $+\sum$ anions $\left.) \times 100\right)$ was calculated to validate the quality of major ion analysis, which was within $<4 \%$. The analysis of heavy metals ( $\mathrm{Cu}, \mathrm{Cr}, \mathrm{Zn}, \mathrm{Ni}, \mathrm{Cd}, \mathrm{Se}, \mathrm{As}, \mathrm{Fe}$ and $\mathrm{Mn}$ ) was conducted at the Laboratory of Plants, Soils, Water and Fertilizer Analysis (LAPSEE) of the Agricultural Research Institute for Development (IRAD) thanks to ICP-OES (Perkin's Elmer 8200). The quality control of the analysis was done using the laboratory reagent blanks as a continuing check on performance. The determined mean concentration from three analyses of the reagent blanks was $\pm 3 \%$ of the stated values.

\section{Data Processing}

The hydrochemical classification of water using the Piper diagram was per- 
formed by the software DIAGAMMES 6.5. The chemical indices used in the evaluation of surface quality for irrigation in the MRB include; Sodium Adsorption Ratio (SAR), Soluble Sodium Percentage (SSP or \%Na), Magnesium Ratio (MAR) and Kelly Ratio (KR).

Sposito \& Mattigod (1977) proposed the calculation of the SAR as follows:

$$
\mathrm{SAR}=\frac{\mathrm{Na}^{+}}{\left[\left(\mathrm{Ca}^{2+}+\mathrm{Mg}^{2+}\right) / 2\right]^{1 / 2}}
$$

Todd (1980) defined the soluble sodium percentage (SSP), or Na\%, as follows:

$$
\mathrm{SSP} \text { or } \% \mathrm{Na}=\frac{\mathrm{Na}^{+}+\mathrm{K}^{+}}{\mathrm{Ca}^{2+}+\mathrm{Mg}^{2+}+\mathrm{Na}^{+}+\mathrm{K}^{+}} \times 100
$$

Paliwal (1972) proposed an index for computing the MAR using the following equation:

$$
\operatorname{MAR}=\frac{\mathrm{Mg}^{2+}}{\mathrm{Ca}^{2+}+\mathrm{Mg}^{2+}} \times 100
$$

(Kelly, 1963) defined Kelly's Ratio (KR) which derived from sodium measured against calcium and magnesium as follows:

$$
\mathrm{KR}=\frac{\mathrm{Na}^{+}}{\mathrm{Ca}^{2+}+\mathrm{Mg}^{2+}}
$$

In these equations, all the concentrations of ions are expressed in $\mathrm{mg} / \mathrm{l}$.

Heavy Metal Pollution Index (HPI) that was proposed by Mohan et al., (1996) is used to access the influence of natural and anthropogenic activities based on the important parameters on water chemistry (Ghaderpoori et al., 2018). The HPI calculation provides a simple indicator of water quality and is based on some very significant heavy metals elements. The relative HPI is computed from the equation below:

$$
\mathrm{HPI}=\frac{\sum_{i=1}^{n} W_{i} Q_{i}}{\sum_{i=1}^{n} W_{i}}
$$

where $n$ is the number of samples considered, $W_{i}$ is the unit weight age of the $i^{\text {th }}$ parameter and $Q_{i}$ is the sub-index of the $I^{\text {th }}$ metallic element. $Q_{i}$ is determined by Equation (2).

$$
Q_{i}=\sum_{i=1}^{n} \frac{\left|M_{i}-I_{i}\right|}{S_{i}-I_{i}} \times 100
$$

where $M_{i}$ is the average concentration of element $i$ in a given sample. $I_{i}$ is the maximum ideal concentration for element $i . S_{i}$ is the standard value of the $i^{\text {th }}$ metallic element. The critical value for HPI is 100 (Prasad \& Bose 2001).

The contamination index $(\mathrm{Cd})$ summarizes the combined effects of several quality parameters considered harmful to domestic water (Backman et al. 1997). It is calculated from equation below:

$$
\mathrm{Cd}=\sum_{i=1}^{n} C_{f i}
$$


where $C_{f i}$ represents the contamination factor.

$$
C_{f i}=\frac{C_{A i}}{C_{N 1}}-1
$$

$C_{N i}$ and $C_{A i}$ represent analytical value and upper permissible concentration of the $i^{\text {th }}$ component, respectively.

The Heavy Metal Evaluation Index (HEI) method gives an overall quality of the water with respect to heavy metals (Edet \& Offiong, 2002). The HEI is computed as:

$$
\mathrm{HEI}=\sum_{i=1}^{n} C_{i} / H_{\max }
$$

where $C_{i}$ is the monitored value of the $i^{\text {th }}$ parameter and $H_{\max }$ the maximum permissible concentration of the $i^{\text {th }}$ metal parameter.

\section{Results and Discussion}

\subsection{General Hydrochemical Characteristics}

Descriptive statistics were used for the hydrochemical characteristics of surface water sampled in the MRB as shown in Table 1 . The $\mathrm{pH}$ values of the study area ranged from $5.45-7.07$, with the mean of $6.67 \pm 0.42$, indicating that the water

Table 1. Hydrochemical parameters and descriptive statistics of the Mungo River and tributaries (major cations and anions, dissolved oxygen (DO) and alkalinity are expressed in $\mathrm{mg} / \mathrm{l}$, total suspended sediments (TSS) in g/l, electrical conductivity (EC) in

\begin{tabular}{|c|c|c|c|c|c|c|c|c|c|c|c|c|c|c|c|c|c|c|}
\hline & Mamfe & Tombel & Bridge & $\begin{array}{l}\text { Con. } \\
\text { Passi }\end{array}$ & Yato & Kobe & LBM & $\begin{array}{c}\text { Kumba } \\
1\end{array}$ & $\begin{array}{c}\text { Kumba } \\
2\end{array}$ & Pete & Yoke & Passi & Min & $\operatorname{Max}$ & Mean & SD & VC & Skewness \\
\hline $\mathrm{pH}$ & 6.98 & 6.72 & 6.78 & 6.9 & 6.85 & 6.56 & 6.91 & 6.51 & 6.74 & 6.57 & 7.07 & 5.45 & 5.45 & 7.07 & 6.67 & 0.42 & 0.06 & -2.47 \\
\hline EC & 29.1 & 30.0 & 35.5 & 53.2 & 54.1 & 31.5 & 54.3 & 39.3 & 44.5 & 40.2 & 167.8 & 16.8 & 16.8 & 167.8 & 49.69 & 38.91 & 0.78 & 2.93 \\
\hline TSS & 41.2 & 8.0 & 31.2 & 37.8 & 31.2 & 9.6 & 10.0 & 34.6 & 38.4 & 35.6 & 0.2 & 14.2 & 0.2 & 41.2 & 24.33 & 14.66 & 0.6 & -0.43 \\
\hline D.O & 91.4 & 97.2 & 95.3 & 75.3 & 86.8 & 97.6 & 88.0 & 72.3 & 93.4 & 75.1 & 88.1 & 73.02 & 72.3 & 97.6 & 86.13 & 9.67 & 0.11 & -0.40 \\
\hline $\mathrm{T}^{\circ} \mathrm{C}$ & 21.8 & 25.0 & 23.2 & 24.6 & 24.2 & 23.2 & 26.7 & 24.1 & 24.7 & 23.7 & 23.4 & 23.7 & 21.8 & 26.7 & 24.0 & 1.19 & 0.05 & 0.43 \\
\hline Alc & 239 & 197 & 216 & 194 & 150 & 239 & 300 & 199 & 228 & 190 & 983 & 100 & 100 & 983 & 269.58 & 229.96 & 0.85 & 3.18 \\
\hline $\mathrm{Ca}$ & 2.22 & 2.18 & 3.25 & 2.20 & 2.22 & 2.33 & 2.55 & 3.18 & 3.60 & 3.19 & 4.70 & 3.27 & 2.18 & 4.70 & 2.91 & 0.77 & 0.27 & 1.10 \\
\hline $\mathrm{Mg}$ & 0.48 & 0.94 & 1.42 & 1.63 & 1.64 & 1.55 & 0.83 & 2.79 & 1.39 & 1.29 & 1.84 & 2.12 & 0.48 & 2.79 & 1.49 & 0.61 & 0.41 & 0.47 \\
\hline $\mathrm{Na}$ & 1.27 & 1.65 & 1.99 & 2.83 & 3.04 & 1.09 & 1.48 & 2.28 & 1.75 & 1.79 & 1.29 & 2.92 & 1.09 & 3.04 & 1.95 & 0.68 & 0.35 & 0.55 \\
\hline $\mathrm{K}$ & 0.80 & 0.94 & 1.29 & 0.87 & 0.77 & 0.56 & 0.87 & 1.01 & 0.9 & 1.09 & 1.55 & 1.44 & 0.56 & 1.55 & 1.01 & 0.29 & 0.29 & 0.65 \\
\hline $\mathrm{NH}_{4}$ & 0.00 & 0.00 & 0.00 & 0.00 & 0.12 & 0.00 & 0.07 & 0.00 & 0.00 & 0.22 & 0.25 & 0.00 & 0.00 & 0.25 & 0.06 & 0.09 & 1.68 & 1.50 \\
\hline $\mathrm{HCO}_{3}$ & 2.5 & 0.5 & 1.9 & 1.9 & 2.3 & 0.6 & 18.3 & 12.1 & 13.9 & 11.6 & 60.0 & 6.1 & 0.5 & 60.0 & 10.98 & 16.57 & 1.51 & 2.71 \\
\hline $\mathrm{SO}_{4}$ & 0.36 & 0.43 & 0.56 & 1.12 & 1.13 & 0.19 & 0.31 & 0.80 & 1.02 & 1.65 & 6.15 & 0.43 & 0.19 & 6.15 & 1.18 & 1.62 & 1.38 & 3.05 \\
\hline $\mathrm{PO}_{4}$ & 0.08 & 0.14 & 0.02 & 0.00 & 0.05 & 0.01 & 0.03 & 0.03 & 0.06 & 0.03 & 0.02 & 0.00 & 0.00 & 0.14 & 0.04 & 0.04 & 1.01 & 1.65 \\
\hline $\mathrm{NO}_{3}$ & 0.00 & 1.30 & 1.15 & 1.21 & 1.43 & 0.99 & 0.34 & 2.87 & 3.44 & 2.08 & 1.49 & 0.53 & 0.00 & 3.44 & 1.4 & 1.00 & 0.71 & 0.80 \\
\hline $\mathrm{Cl}$ & 0.22 & 0.25 & 0.40 & 0.68 & 0.69 & 0.44 & 0.63 & 1.23 & 1.45 & 0.86 & 2.78 & 0.89 & 0.22 & 2.78 & 0.88 & 0.7 & 0.8 & 1.99 \\
\hline $\mathrm{F}$ & 0.04 & 0.05 & 0.05 & 0.05 & 0.03 & 0.04 & 0.04 & 0.04 & 0.04 & 0.05 & 0.10 & 0.01 & 0.01 & 0.1 & 0.05 & 0.02 & 0.46 & 1.48 \\
\hline
\end{tabular}
$\mu \mathrm{s} / \mathrm{cm})$. 
were slightly acidic. The Electrical Conductivity (EC) measured in all samples ranged between $16.80-167.78 \mu \mathrm{s} / \mathrm{cm}$, with an average of $48.90 \pm 38.91 \mu \mathrm{s} / \mathrm{cm}$. In the main course of the Mungo River, the EC values increase downstream after the confluence of the Yoke tributary where the highest EC value was obtained. These EC of surface water were basically lower than the WHO permissible limits $(1000 \mu \mathrm{s} / \mathrm{cm})$. From the average ion concentrations, the relative abundance of cations and anions were as follows: $\mathrm{Ca}^{2+} 39.2 \%>\mathrm{Na}^{+} 26.3 \%>\mathrm{Mg}^{2+} 20.1 \%>\mathrm{K}^{+}$ $13.6 \%$ and $\mathrm{HCO}_{3}^{-} 75.6 \%>\mathrm{NO}_{3}^{-} 9.7 \%>\mathrm{SO}_{4}^{2-} 8.1 \%>\mathrm{Cl}^{-} 6.0 \%$. The concentration of total suspended sediments (TSS) was higher in the main course of the Mungo River and in urban tributaries, which could result from sand quarry activities and urban runoff, generating high turbidity.

In general low concentrations of ions were obtained for all the water samples. $\mathrm{Ca}^{2+}, \mathrm{Na}^{+}, \mathrm{Mg}^{2+}$ and $\mathrm{K}^{+}$have normal distributions, with skewness values lower than 2 and $\mathrm{VCs}$ lower than 0.5 . However, skewness values of $\mathrm{HCO}_{3}^{-}, \mathrm{SO}_{4}^{2-}$ and $\mathrm{Cl}^{-}$were $\geq 2$ and their $\mathrm{VCs}$, including $\mathrm{NO}_{3}^{-}$were $>0.5$, showing heterogeneous distribution that would result from the highest concentration of observed in Yoke stream. A positive correlation were observed between $\mathrm{Ca}^{2+}$ vs. $\mathrm{Cl}^{-}+$ $\mathrm{SO}_{4}^{2-}+\mathrm{NO}_{3}^{-}$and $\mathrm{Cl}^{-}$vs. $\mathrm{SO}_{4}^{2-}+\mathrm{NO}_{3}^{-}$(Figure 2), indicating that these species are belonging to the same geogenic sources and may be affected by the same processes. The highest concentrations and VCs recorded at Yoke and Kumba could suggest additional influences in this sampling sites.

The Piper diagram is suited for graphical presentation of the major ions to quickly determine the hydrochemical facies of the surface water (Zhang et al., 2019; Jiang et al., 2020). The hydrochemical types in the MRB are presented in Figure 3. It can be seen from the anion distribution that the dispersion of $\mathrm{HCO}_{3}^{-}$dominated the waters, while some sampling points were controlled by $\mathrm{NO}_{3}^{-}$and $\mathrm{SO}_{4}^{2-}$. From the cation distribution, all water sample points fell in the center of the triangle, which is the mixing zone. The $\mathrm{Ca}-\mathrm{HCO}_{3}$ water type occur in all the water samples. The dominant hydrochemical type of the surface water of the MRB was $\mathrm{Ca}-\mathrm{Na}-\mathrm{HCO}_{3}-\mathrm{NO}_{3}$, followed by $\mathrm{Ca}-\mathrm{Mg}-\mathrm{HCO}_{3}-\mathrm{SO}_{4}$. The hydrochemical type of the Lake Barumbi Mbo was Ca-Na- $\mathrm{HCO}_{3}$, shifting downstream in Kumba stream to Ca-Mg- $\mathrm{HCO}_{3}-\mathrm{NO}_{3}$ or $\mathrm{Ca}-\mathrm{Na}-\mathrm{HCO}_{3}-\mathrm{NO}_{3}$ type.

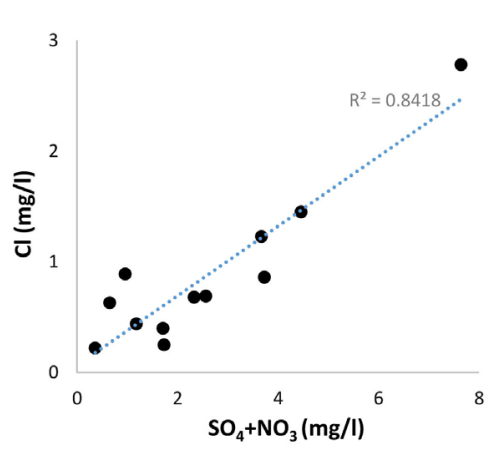

(a)

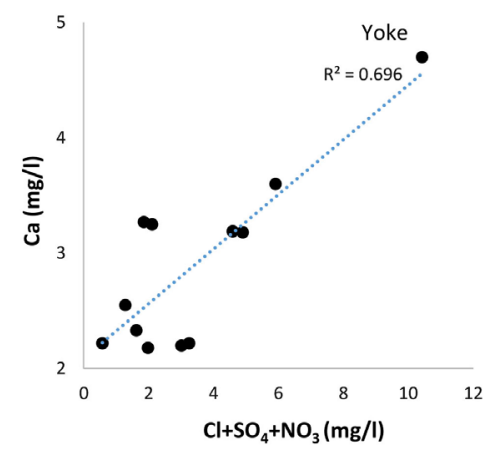

(b)

Figure 2. Linear correlation of water quality parameters. 


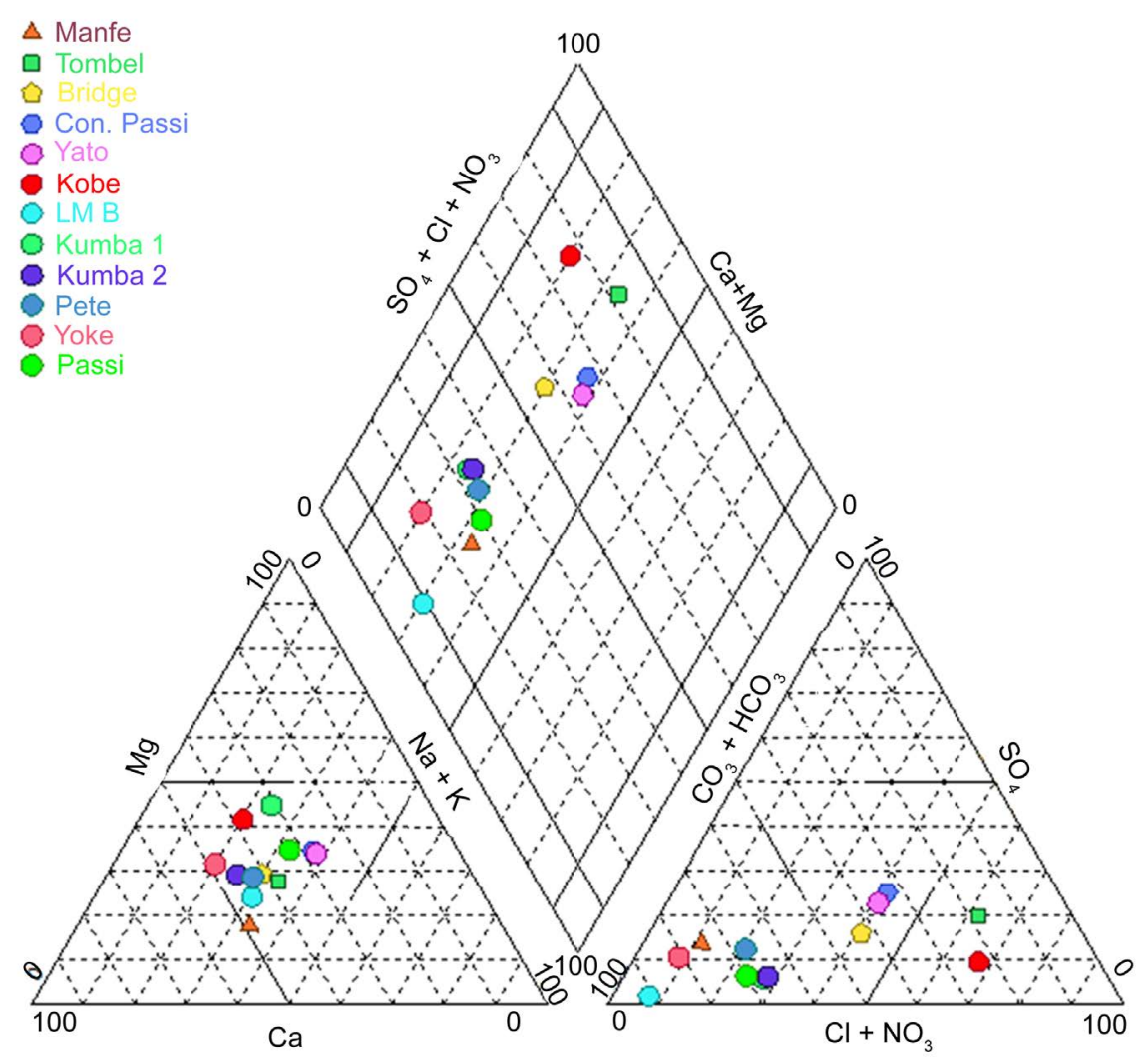

Figure 3. Piper plot of analyzed surface water characteristics in the MRB.

\subsection{Origin of Major Ions}

Gibbs diagram (Figure 4(a)) which shows the relative fractions for ions plotted against the total dissolved solids (TDS) on a logarithmic axis, indicates that the samples are mainly in the atmospheric control area, extending toward the rock-weathering control area. The $\mathrm{Ca}^{2+} / \mathrm{Na}^{+}$versus $\mathrm{Mg}^{2+} / \mathrm{Na}^{+}$and $\mathrm{HCO}_{3}^{-} / \mathrm{Na}^{+}$ ratios (Figure 4(b) and Figure 4(c)) were analyzed to determine the type of rock weathering source associated with the surface water chemistry characteristics (Isidoro \& Aragüés, 2007). The results indicate that the source of chemical components in surface water of the study area is dominated by the weathering of silicate rock. This is consistent with the results in the Gibbs diagram, in which the samples get closer to atmospheric with a trend towards rock-weathering control areas. This suggests that rock weathering is apparently the dominant process influencing surface water hydrochemistry in the study area. Ako et al. (2012) studied spring water chemistry in the area of mount Cameroon in which the downstream river system of the MRB originates and observed that two main water types $\left(\mathrm{Ca}-\mathrm{Mg}-\mathrm{HCO}_{3}\right.$ and $\left.\mathrm{Ca}-\mathrm{Na}-\mathrm{HCO}_{3}\right)$ represent spring waters in this area. This is consistent with the results obtained in the present study. In another study Benedetti et al. (2003) have found that there are no significant carbonate minerals in the soils and aquifers in this area implying that the dominance of bicarbonate water type could therefore be the result of the weathering of volcanic rocks. We therefore conclude that the weathering of volcanic rocks is the major 

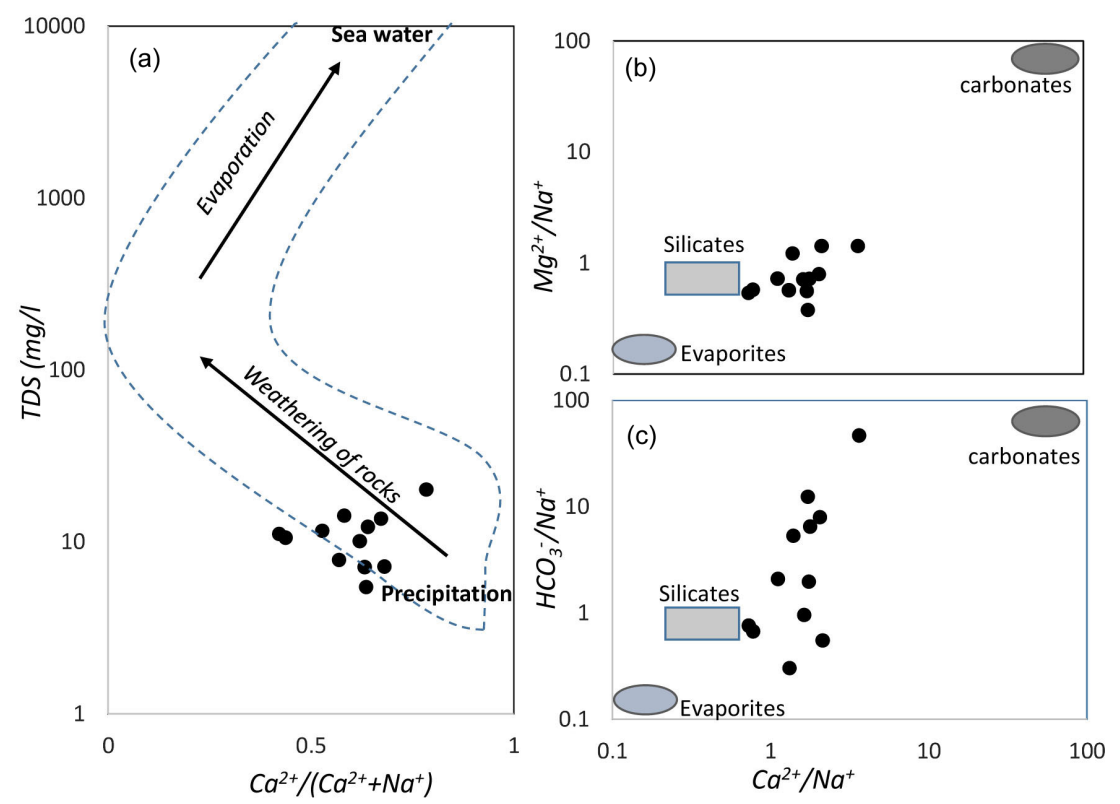

Figure 4. Gibbs (1970) plot for cations (a); end-member diagrams of ionic ratios in surface water ((b) and (c)).

control on the stream and spring water compositions. This assertion is consolidated by Ako et al. (2012) who indicated that cations and bicarbonate ions are derived from weathering of the basaltic minerals, and this occurs primarily within the aquifer where waters are in contact with fresh basaltic minerals. Although $\mathrm{Cl}^{-}$, $\mathrm{SO}_{4}^{2-}$ and $\mathrm{NO}_{3}^{-}$concentrations were low, relatively significant concentration were founded in Yoke and Kumba, indicating additional sources for these species. Ako et al. (2012) found that oceanic monsoon chloride-rich/sulfate-rich rainwater seems to affect spring water chemistry at low-altitude, what could be the case for Yoke where high $\mathrm{Cl}^{-}, \mathrm{SO}_{4}^{2-}$ concentrations were observed. Elsewhere, leaching through urban leaching may contribute nitrates to Kumba stream.

\subsection{Heavy Metal Composition}

Results of heavy metal analysis for the MRB are given in Table 2. $\mathrm{Cu}, \mathrm{Cr}$ and $\mathrm{Ni}$ were below the detection limit in all the sampling points, while $\mathrm{Zn}$ and Se were detected in only two sites (Manfe and Tombel), with concentrations not exceeding 0.005 and $0.03 \mu \mathrm{g} / \mathrm{l}$ respectively. Cd was found downstream of the Mungo River at Con. Passi and Yato and in all the tributaries, with concentrations varying between 0.06 and $0.74 \mu \mathrm{g} / \mathrm{l}$, with an average of $0.31 \pm 0.27 \mu \mathrm{g} / \mathrm{l}$. As was found in all the sampling points, with concentrations between 0.01 and $0.96 \mu \mathrm{g} / \mathrm{l}$, with a mean of $0.21 \pm 0.30 \mu \mathrm{g} / \mathrm{l}$. Although Fe was not found in all samples, it appears in a wide range, from 1 to $364 \mathrm{mg} / \mathrm{l}$, significant concentrations been observed in the Mungo River at Manfe $(40 \mathrm{mg} / \mathrm{l})$ and Yoke stream $(100 \mathrm{mg} / \mathrm{l})$ and the highest concentration of $364 \mathrm{mg} / \mathrm{l}$ exceeding the WHO (2011) limit observed in Passi stream. Mn appeared only associated with high Fe concentration at Yoke and Passi, where it had concentrations of 6 and $21 \mathrm{mg} / \mathrm{l}$ respectively. The correlation 
Table 2. The concentrations of heavy metals (in $\mu \mathrm{g} / \mathrm{l}$ ) in the Mungo River Basin (Fe and $\mathrm{Mn}$ are expressed in $\mathrm{mg} / \mathrm{l}$ ) and applied standards for calculation of HPI and HEI.

\begin{tabular}{|c|c|c|c|c|c|c|c|c|c|c|c|c|}
\hline & Mamfe & Tombel & Con, Passi & Yato & LMB & Kumba2 & Yoke & Passi & MCL & $\mathbf{W i}$ & Ii & $\mathrm{Si}$ \\
\hline $\mathrm{Fe}$ & 40 & bdl & bdl & 1 & bdl & 1 & 100 & 364 & 200 & 0.005 & 200 & 300 \\
\hline Mn & bdl & 1 & bdl & bdl & bdl & bdl & 6 & 21 & 50 & 0.02 & 500 & 100 \\
\hline $\mathrm{Cu}$ & bdl & bdl & bdl & bdl & bdl & bdl & bdl & bdl & 1000 & 0.001 & 2000 & 1000 \\
\hline $\mathrm{Zn}$ & 0.005 & 0.003 & bdl & bdl & 0.17 & bdl & bdl & bdl & 5000 & 0.0002 & 3000 & 5000 \\
\hline $\mathrm{Ni}$ & bdl & bdl & bdl & bdl & bdl & bdl & bdl & bdl & & & & \\
\hline $\mathrm{Cd}$ & bdl & bdl & 0.066 & 0.059 & 0.45 & 0.41 & 0.74 & 0.116 & 3 & 0.3 & 3 & 5 \\
\hline $\mathrm{Se}$ & 0.027 & 0.018 & bdl & bdl & bdl & bdl & bdl & bdl & & & & \\
\hline As & 0.108 & 0.106 & 0.104 & 0.097 & 0.109 & 0.109 & 0.1 & 0.96 & 50 & 0.02 & 10 & 50 \\
\hline $\mathrm{Cr}$ & bdl & bdl & bdl & bdl & bdl & bdl & bdl & bdl & 50 & 0.02 & 50 & 1 \\
\hline $\mathrm{Pb}$ & na & na & na & na & na & na & na & na & 1.5 & 0.7 & 10 & 100 \\
\hline
\end{tabular}

bdl (below the detection limit); na (not analyzed).

among the physico-chemical properties ( $\mathrm{pH}$ and $\mathrm{EC}$ ) and significant heavy metals (Cd and As) concentrations were studied to characterize the origin of heavy metals in the MRB. High As concentration was correlated with lower $\mathrm{pH}$ and high Cd concentration with high CE (Figure 5). This pattern of As and Cd could suggest natural source controlling these heavy metals in the study area. Indeed, the low concentrations of heavy metal observed in the MRB could be related to the pedo-geochemical background of the studied area. This observation can be justified by the positive correlation observed between $\mathrm{CE}$ and Cd, almost related to silicate weathering. The high concentrations of Fe and Mn observed at Passi were associated to low $\mathrm{pH}$ and may be released from the soil and the aquifer. Ngon Ngon et al. (2015) found that the lithology of this coastal plain is made up of clayey materials, generally ferruginous, in which iron and manganese nodules can be found. Dissolution of iron and manganese nodules in clay soil can be considered through chemical reactions of $\mathrm{Fe}$ and $\mathrm{Mn}$ oxides in the aquifer:

$$
\begin{aligned}
& \mathrm{CH}_{2} \mathrm{O}+2 \mathrm{MnO}_{2}+3 \mathrm{H}^{+}=2 \mathrm{Mn}^{2+}+\mathrm{HCO}_{3}^{-}+2 \mathrm{H}_{2} \mathrm{O} \\
& \mathrm{CH}_{2} \mathrm{O}+4 \mathrm{Fe}(\mathrm{OH})_{3}+7 \mathrm{H}^{+}=4 \mathrm{Fe}^{2+}+\mathrm{HCO}_{3}^{-}+10 \mathrm{H}_{2} \mathrm{O}
\end{aligned}
$$

According to Rawson et al. (2017), this dissolution of Fe and Mn minerals causes As adsorbed on them to be released into the water system. This may explain the relatively high concentration of As $(0.96 \mu \mathrm{g} / \mathrm{l})$ associated with high concentration of $\mathrm{Fe}$ and $\mathrm{Mn}$ recorded in Passi stream. The low concentration of heavy metals could be the results of dilution since sampling was done during the rainy season (Yi et al., 2020). In addition, within the observed $\mathrm{pH}$ range, some metals such as $\mathrm{As}, \mathrm{Cd}, \mathrm{Cu}, \mathrm{Cr}$ and $\mathrm{Ni}$ would precipitate, lowering the concentration of the dissolved fraction (El Bouraie et al., 2010). This process may explain the absence of these metals in some sampling points. 


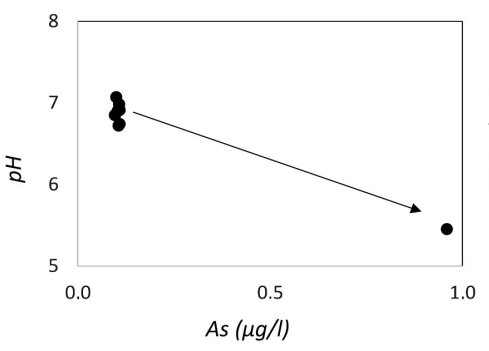

(a)

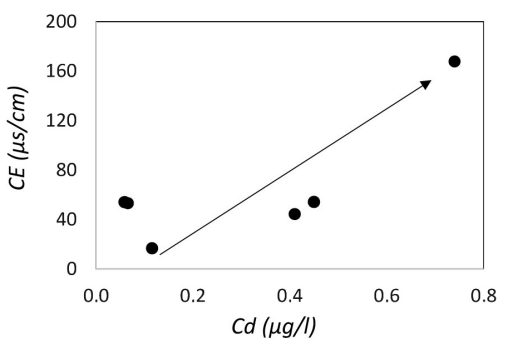

(b)

Figure 5. Relationship between $\mathrm{pH}$ vs. As (a) and CE vs. Cd (b).

\subsection{Water Quality Assessment for the Study Area}

\subsubsection{Suitability of Surface Water for Agriculture}

The calculations of four indices of sodium related parameters (SAR, SSP, MAR and KR) were performed to analyze the irrigation suitability of surface water in the study area (Table 3). SAR represents the relative activity of $\mathrm{Na}^{+}$in soil exchange reactions and is used to evaluate the degree of alkalization of water. From the classification of irrigation suitability made by Richards (1954) four types of water can be distinguished as excellent $(<10)$, good (10 - 18), doubtful $(19-26)$ and unsuitable (>26). As shown in Figure 6(a), all samples in the study area are suitable for agricultural irrigation based on SAR values. The suitability for irrigation based on SSP was classified as excellent $(<20 \%)$, good $(20 \%-40 \%)$, doubtful $(40 \%-60 \%)$ or unsuitable $(60 \%-80 \%)$. In the study area, approximately $58 \%$ of water samples were found as doubtful with regard to SSP, while $42 \%$ was good for irrigation (Figure 6(b)). According to Szabolcs and Darab (1964), the safe limit for MAR is 50 above which the water is not suitable for irrigation. As shown in Figure 6(c), all the water samples were within the safe limit and do not pose threat due to magnesium. When classifying the suitability of irrigation water based on $\mathrm{KR}$, a value more than 1 means that there is too much sodium in water for irrigation and a value less than 1 means the water is suitable for irrigation. In the study area, all the water samples were suitable for irrigation with regard to KR (Figure 6(d)).

The irrigation suitability evaluation of surface water in the MRB based on SAR, SSP, MAR and KR showed that all the surface water is suitable for irrigation. Although the SSP showed $58 \%$ of doubtful samples, the influence of $\mathrm{Na}$ concentration on irrigation suitability can be minimized because these samples are not in a critical state (Table 4). In fact carbonate and bicarbonate are in very low concentrations to form precipitates with calcium and magnesium that reduces the permeability. Nevertheless, the high SSP observed downstream of the Mungo River may be indicative of an early marine salt rise at these points which are located in the areas where the river water is pumped for drinking and irrigation purposes.

\subsubsection{Suitability of Surface Water for Drinking Purpose}

The calculated heavy metal pollution index (HPI), contamination index (Cd) and heavy metal evaluation index (HEI) for surface water, based on monitored 


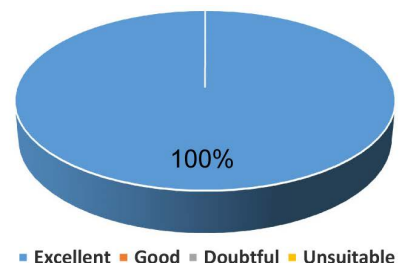

(a)

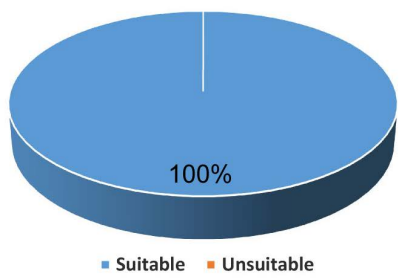

(c)

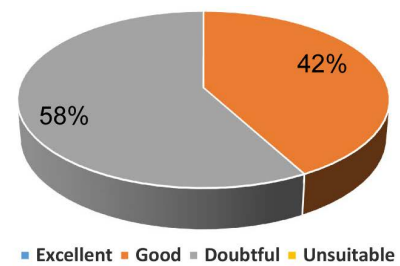

(b)

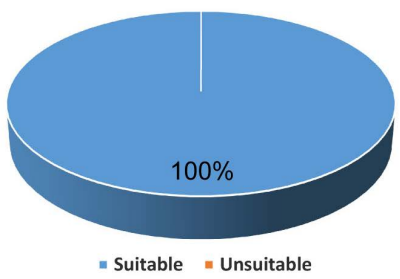

(d)

Figure 6. Water suitability based on SAR, Na\%, MAR and KR. (a) SAR; (b) SSR or NA\%; (c) MAR; (d) KR.

Table 3. The calculated indexes of sodium related parameters at the sampling points.

\begin{tabular}{cccccccccccccc}
\hline & Mamfe & Tombel Bridge & $\begin{array}{c}\text { Con. } \\
\text { Passi }\end{array}$ & Yato & Kobe & LBM & \multicolumn{2}{c}{ Kumba Kumba } & Pete Yoke Passi \\
\hline $\begin{array}{c}\text { SSP } \\
(\mathrm{Na} \%)\end{array}$ & 43.4 & 45.4 & 41.3 & 49.1 & 49.7 & 29.8 & 41.0 & 35.5 & 34.7 & 39.1 & 30.3 & 44.7 \\
SAR & 1.1 & 1.3 & 1.3 & 2.0 & 2.2 & 0.8 & 1.1 & 1.3 & 1.1 & 1.2 & 0.7 & 1.8 \\
KR & 0.5 & 0.5 & 0.4 & 0.7 & 0.8 & 0.3 & 0.4 & 0.4 & 0.4 & 0.4 & 0.2 & 0.5 \\
MAR & 17.8 & 30.1 & 30.4 & 42.6 & 42.5 & 39.9 & 24.6 & 46.7 & 27.9 & 28.8 & 28.1 & 39.3 \\
\hline
\end{tabular}

Table 4. The calculated indices, HPI and HEI, at the sampling points for heavy metals.

\begin{tabular}{ccccccccc}
\hline & Mamfe & Tombel & Con. Passi & Yato & LBM & Kumba2 & Yoke & Passi \\
\hline Cd & -7.80 & -7.98 & -7.98 & -7.97 & -7.85 & -7.86 & -7.13 & -5.70 \\
HPI & 55.45 & 55.63 & 54.71 & 54.80 & 49.28 & 49.84 & 44.68 & 53.69 \\
HEI & 0.20 & 0.02 & 0.02 & 0.03 & 0.15 & 0.14 & 0.87 & 2.30 \\
\hline
\end{tabular}

values of heavy metal and the used constants of $\mathrm{Mn}, \mathrm{Cu}, \mathrm{Zn}, \mathrm{Cd}, \mathrm{As}, \mathrm{Cr}$ and $\mathrm{Pb}$ are presented in Table $4 . \mathrm{Pb}$ was not analyzed in this study and its concentration was assumed to $0 \mu \mathrm{g} / \mathrm{l}$, the same applied to other metals whose concentration was below the detection limit (bdl). The threshold risk for water quality based on HPI is 100 (Prasad \& Bose, 2001; Ghaderpoori et al., 2018). If HPI is more than 100 , water cannot be used for drinking. Measured values of HPI index for this study was below 100 (44.68 - 55.63), indicating that all the surface waters of the study area was suitable for drinking purpose with regard to heavy metals. The contamination index $(\mathrm{Cd})$ was used as reference to estimate the extent of metal pollution. According to Al-Ami et al. (1987), Cd may be grouped into three categories as follows: low $(\mathrm{Cd}<1)$, medium $(\mathrm{Cd}=1-3)$ and high $(\mathrm{Cd}>3)$. The range of value of $\mathrm{Cd}$ in this study was -7.98 to -5.70 , suggesting the absence of 
pollution for these waters. Edet and Offiong (2002) proposed the classifications of the HEI index as follows: low (less than10), medium (between 10 and 20) and high (more than 20). The level of HEI in surface water of the MRB (between 0.02 and 2.3) shows that the water quality falls within the zone of water suitable for drinking.

\section{Conclusion}

Based on the data of stream hydrochemistry and heavy metals, the surface water quality of the Mungo River Basin, one of the most important agricultural basins in Cameroon, has been evaluated for multipurpose uses, aiming to understand the processes controlling the regional hydrochemistry and to assess the suitability of surface water for irrigation and drinking purposes.

Low content of ions was recorded in this study area and normal distribution was found for cations. Heterogeneous distribution was observed for $\mathrm{HCO}_{3}^{-}$, $\mathrm{SO}_{4}^{2-}, \mathrm{Cl}^{-}$and $\mathrm{NO}_{3}^{-}$due to relatively high concentrations observed in Yoke and Kumba streams. The hydrochemistry was dominated by two types, the $\mathrm{Ca}-\mathrm{Na}-\mathrm{HCO}_{3}-\mathrm{NO}_{3}$ and $\mathrm{Ca}-\mathrm{Mg}-\mathrm{HCO}_{3}-\mathrm{SO}_{4}$. The chemical composition was mainly affected by silicate weathering; there is a partial influence of atmospheric input from chloride-rich/sulfate-rich rainwater at Yoke stream. Despite the agro-industrial and agricultural activities and the inflow of urban/suburban sewage, the effects of anthropogenic source pollution were less marked in the hydrochemistry of the surface water, significant concentration of $\mathrm{NO}_{3}^{-}$recorded in Kumba stream has been attributed to urban leaching. Very low concentrations of heavy metals were found in the study area, far below the WHO permissible limits for drinking water, except Fe at Passi stream, which concentration exceeded the permissible limit and might be due to the release from soil and aquifer following the dissolution of iron minerals of ferruginous nodules in clayey soil.

Despite the fact that $58 \%$ of water samples were found doubtful with regard to SSP, carbonate and bicarbonate were in very low concentrations to form precipitates that affect permeability. Hence, the evaluation of surface water for irrigation and drinking purposes based on SAR, SSP, MAR and KR showed that all the surface water was below the critical limits and then suitable human uses.

\section{Acknowledgements}

We sincerely thank the Laboratory of Water Analysis (LAGE) of the Institute of Geological and Mining Research (IRGM) for ions analysis and the Laboratory of Plants, Soils, Water and Fertilizer Analysis (LAPSEE) of the Agricultural Research Institute for Development (IRAD) for heavy metals analysis.

\section{Conflicts of Interest}

The authors declare no conflicts of interest regarding the publication of this paper. 


\section{References}

Ako A. A, Eyong, G. E. T., Shimada, J., Koike, K., Hosono, T., Kimpei, I. et al. (2014). Nitrate Contamination of Groundwater in Two Areas of the Cameroon Volcanic Line (Banana Plain and Mount Cameroon Area). Applied Water Science, 4, 99-113. https://doi.org/10.1007/s13201-013-0134-X

Ako, A. A., Shimada, J., Hosono, T., Kagabu, M., Akoachere, R.A., Elambo, G. N. et al. (2012). Spring Water Quality and Usability in the Mount Cameroon Area Revealed by Hydrogeochemistry. Environmental Geochemistry and Health, 34, 615-639. https://doi.org/10.1007/s10653-012-9453-3

Al-Ami, M. Y., Al-Nakib, S. M., Ritha, N. M., Nouri, A. M., \& Al-Assina, A. (1987). Water Quality Index Applied to the Classification and Zoning of Al-Jaysh Canal, Bagdad, Iraq. Journal of Environmental Science and Health, 22, 305-319. https://doi.org/10.1080/10934528709375351

Aminiyan, M. M., Aminiyan, F. M., \& Heydariyan, A. (2016). Study on Hydrochemical Characterization and Annual Changes of Surface Water Quality for Agricultural and Drinking Purposes in Semi-Arid Area. Sustainable Water Resources Management, 2, 473-487. https://doi.org/10.1007/s40899-016-0071-6

Backman, B., Bodis, D., Lahermo, P., Rapant, S., \& Tarvainen, T. (1997). Application of a Groundwater Contamination Index in Finland and Slovakia. Environmental Geology, 36, 55-64. https://doi.org/10.1007/s002540050320

Bartarya, S. K. (1993). Hydrochemistry and Rock Weathering in a Sub-Tropical Lesser Himalayan River Basin in Kumaun, India. Journal of Hydrology, 143, 149-174. https://doi.org/10.1016/0022-1694(93)90274-D

Benedetti, M. F., Dia, A., Riotte, J., Chabaux, F., Gerald, M., Boulègue, J. et al. (2003). Chemical Weathering of Basaltic Lava Flows Undergoing Extreme Climatic Conditions: The Water Geochemistry Record. Chemical Geology, 201, 1-17. https://doi.org/10.1016/S0009-2541(03)00231-6

Brindha, K., \& Kavitha, R. (2015). Hydrochemical Assessment of Surface Water and Groundwater Quality along Uyyakondan Channel, South India. Environmental Earth Sciences, 73, 5383-5393. https://doi.org/10.1007/s12665-014-3793-5

Driessen, P. M., \& Dudal, R. (1991). The Major Soils of the World. Lecture Notes on Their Geography, Formation, Properties and Land Use (310 p). Wageningen: Agricultural University of Wagenningen.

Edet, A.E., \& Offiong, O.E. (2002). Evaluation of Water Quality Pollution Indices for Heavy Metal Contamination Monitoring. A Study Case from Akpabuyo-Odukpani Area, Lower Cross River Basin (Southeastern Nigeria). GeoJournal, 5, 295-304. https://doi.org/10.1023/B:GEJO.0000007250.92458.de

El Bouraie, M. M., El Barbary, A. A., Yehia, M. M., \& Motawea, E. A. (2010). Heavy Metal Concentrations in Surface River Water and Bed Sediments at Nile Delta in Egypt. Finnish Peatland Society, 61, 1-12.

Endeley, R. E., Ayonghe, S. N., \& Tchuenteu, F. (2001). A Preliminary Hydrochemical Baseline Study of Water Sources around Mount Cameroon. Journal of the Cameroon Academy of Sciences, 1, 161-167.

Gèze, B. (1943). Géographie physique et géologie du Cameroun Occidental. Mémoire du Muséum National d'Histoire Naturelle (273 p.). Nlle série, t. XVII, Fascicule unique.

Ghaderpoori, M., kamarehie, B., Jafari, A., Ghaderpoury, A., \& Karami, M. (2018). Heavy Metals Analysis and Quality Assessment in Drinking Water-Khorramabad City, Iran. Data in Brief, 16, 685-692. https://doi.org/10.1016/j.dib.2017.11.078 
Gibbs, R. J. (1970). Mechanisms Controlling World Water Chemistry. Science, 170, 1088-1090. https://doi.org/10.1126/science.170.3962.1088

Güler, C., \& Thyne, G. D. (2004). Hydrologic and Geologic Factors Controlling Surface and Groundwater Chemistry in Indian Wells-Owens Valley Area, Southeastern California, USA. Journal of Hydrology, 225, 177-198. https://doi.org/10.1016/j.jhydrol.2003.08.019

Huang, G. X., Chen, Z. Y., \& Sun, J. C. (2014). Water Quality Assessment and Hydrochemical Characteristics of Groundwater on the Aspect of Metals in an Old Town, Foshan, South China. Journal of Earth System Science, 123, 91-100. https://doi.org/10.1007/s12040-013-0370-3

Isidoro, D., \& Aragüés, R. (2007). River Water Quality and Irrigated Agriculture in the Ebro Basin: An Overview. Water Resources Development, 23, 91-106. https://doi.org/10.1080/07900620601159743

Jiang, Y., Gui. H., Yu, H., Wang, M., Fang, H., Wang, C. et al. (2020). Hydrochemical Characteristics and Water Quality Evaluation of Rivers in Different Regions of Cities: A Case Study of Suzhou City in Northern Anhui Province, China. Water, 12, Aticle No. 950. https://doi.org/10.3390/w12040950

Kelly, W. P. (1963). Use of Saline Irrigation Water. Soil Science, 95, 385-391. https://doi.org/10.1097/00010694-196306000-00003

Khatri, N., \& Tyagi, S. (2014). Influences of Natural and Anthropogenic Factors on Surface and Groundwater Quality in Rural and Urban Areas. Frontiers in Life Science, 8, 23-39. https://doi.org/10.1080/21553769.2014.933716

Martin, D., \& Sieffermann, G. (1966). Le département du Mungo (Ouest-Cameroun): Etude des sols et de leur utilisation. Cahier ORSTOM Série Pédologie, 4, 27-49.

Mohan, S. V., Nithila, P., \& Reddy, S. J. (1996). Estimation of Heavy Metal in Drinking Water and Development of Heavy Metal Pollution Index. Journal of Environmental Science and Health, 31, 283-289. https://doi.org/10.1080/10934529609376357

Ngon Ngon, G. F., Etame, J., Ntamak-Nida, M. J., Mbesse, C. O., Mbai, J. S., Bayiga, E. C. et al. (2015). Geochemical and Palaeoenvironmental Characteristics of Missole I Iron Duricrusts of the Douala Sub-Basin (Western Cameroon). Comptes Rendus Geoscience, 348, 127-137. https://doi.org/10.1016/j.crte.2015.10.006

Olivry, J. C. (1986). Fleuves et rivieres du Cameroun (No. 9, 733 p). In Collection Monographie Hydrologique. Paris: MESRES-ORSTOM.

Paliwal, K. V. (1972). Irrigation with Saline Water (p 198.). Monogram No. 2 (New series). New Delhi: Indian Agricultural Research Institute.

Prasad, B., \& Bose, J. M. (2001). Evaluation of Heavy Metal Pollution Index for Surface and Spring Water Near a Limestone Mining Area of the Lower Himalayas. Environmental Geology, 41, 183-188. https://doi.org/10.1007/s002540100380

Rawson, J., Siade, A., Sun, J., Neidhardt, H., Berg, M., \& Prommer, H. (2017). Quantifying Reactive Transport Processes Governing Arsenic Mobility after Injection of Reactive Organic Carbon into a Bengal Delta Aquifer. Environmental Science \& Technology, 51, 8471-8480. https://doi.org/10.1021/acs.est.7b02097

Richards, L. A. (1954). Diagnosis and Improvement of Saline and Alkaline Soils (Vol. 60, 160 p). In Handbook. Washington DC: US Department of Agriculture.

Sanga, A.B., Melisa, B., Fantong, W.Y., Banseka, H. S., \& Ayonghe, S. (2020). Major Ions, $\delta \mathrm{D}, \delta^{18} \mathrm{O}$ and Microbial Characterization of Drinking Water Sources along the West Coast of Cameroon. Environ Earth Sci, 79, Article No. 106. 
https://doi.org/10.1007/s12665-020-8837-4

Sieffermann, G. (1973). Les sols de quelques régions volcaniques du Cameroun: Variation pédologiques et minéralogiques du milieu équatorial au milieu tropical. Mémoires ORSTOM $\mathrm{N}^{\circ} 66$, Paris.

Sposito, G., \& Mattigod, S. V. (1977). On the Chemical Foundation of the Sodium Adsorption Ratio. Soil Science Society of America, 41, 323-329. https://doi.org/10.2136/sssaj1977.03615995004100020030x

Szabolcs, I., \& Darab, C. (1964). The Influence of Irrigation Water of High Sodium Carbonate Content of Soils. In I. Szabolics (Ed.), Proceedings of 8th International Congress Soil Science Sodics Soils, Research Institute for Soil Science and Agricultural Chemistry of the Hungarian Academy of Sciences (pp. 802-812), ISSS Trans II, Tsukuba, Japan.

Tabot, P. T., Che, C. A., \& Fonge, B. A. (2016). Water Quality of Lake Barombi Mbo, A Volcanic Crater Lake and Associated Point Sources. International Journal of Current Microbiology and Applied Sciences, 5, 518-536. https://doi.org/10.20546/ijcmas.2016.507.057

Tamen, J., Nkoumbou, C., Mouafo, L., Reusser, E., \& Tchoua, F. M. (2007). Petrology and Geochemistry of Monogenetic Volcanoes of the Barombi Koto Volcanic Field (Kumba Graben, Cameroon Volcanic Line): Implications for Mantle Source Characteristics. Comptes Rendus Geoscience, 339, 799-809. https://doi.org/10.1016/j.crte.2007.09.007

Todd, D. K. (1980). Groundwater Hydrology (552 pp.). New York, NY: Wiley.

Winter, T. C., Harvey, J. W., Franke, O. L., \& Alley, W. M. (1998). Ground Water and Surface Water: A Single Resource. USGS Numbered Series No. 1139, Reston, VA: U.S. Geological Survey.

World Health Organization (WHO) (1993). Guidelines for Drinking-Water Quality (2nd ed.). WHO Technical Report Series, Geneva: World Health Organization.

World Health Organization (WHO) (2011). Guidelines for Drinking-water Quality (4th ed.). WHO Technical Report Series, Geneva: World Health Organization.

Wotany, E. R., Ayonghe, S., Fantong, W. Y., Wirmvem M. J., \& Takeshi O. (2013). Hydrogeochemical and Anthropogenic Influence on the Quality of Water Sources in the Rio del Rey Basin, South Western, Cameroon, Gulf of Guinea. African Journal of Environmental Science and Technology, 7, 1053-1069.

Yi, L., Gao, B., Liu, H., Zhang, Y., Du, C., \& Li, Y. (2020). Characteristics and Assessment of Toxic Metal Contamination in Surface Water and Sediments Near a Uranium Mining Area. Int. J. Environ. Res. Public Health, 17, Article No. 548.

https://doi.org/10.3390/ijerph17020548

Zhang, W.Y., Ma, L., Abuduwaili, J., Ge., Y.X., Issanova. G., \& Saparov, G. (2019). Hydrochemical Characteristics and Irrigation Suitability of Surface Water in the Syr Darya River, Kazakhstan. Environmental Monitoring and Assessment, 191, Article No. 572. https://doi.org/10.1007/s10661-019-7713-8 